\title{
Creating and using a computer debt simulation model for teaching the economics of developing countries
}

\author{
Linda Paul Kinney
}

Shepherd College

Shepherdstown

West Virginia

USA

Elizabeth S. Adams

Richard Stockton College of New Jersey

USA

\begin{abstract}
This paper describes the motivation for and the use of software to clarify and elucidate concepts in economics. The computer model designed and implemented by a computer scientist and an economist, enables students to manipulate data in order to more fully understand the factors involved in the accumulation and repayment of international debt by developing countries. The paper discusses the value of such a model in the economics classroom and encourages computer scientists to form partnerships with faculty in other disciplines to help them integrate computer usage into their curriculum.
\end{abstract}

Main conference themes: software

Educational areas: higher education

Study topics: economics

Secondary keywords: curriculum development, modelling, teaching materials 


\section{INTRODUCTION}

This paper describes the motivation for and the use of software to clarify and elucidate concepts in economics. A computer simulation model was designed and implemented to enable students to manipulate data in order to more fully understand the factors involved in the accumulation and repayment of international debt by developing countries. The model was developed by an economist and a computer scientist, and illustrates the educational benefits which can result from this kind of partnership. Both faculty members feel that their teaching has benefited from the collaboration and that having students collaborate in a similar manner would be valuable.

\section{What economists do: context for the model}

Economists who advise business and government, often make predictions about the future impact of various policies and initiatives to help guide decision making and long term planning. Forecasters must have knowledge of sources of relevant data. They must be able to manipulate data relating to the phenomena to be forecast. They must thoroughly understand the causal factors and must be able to judge which of many possible future scenarios are most probable.

The efficiency and convenience of computers and the multitude of software available today have greatly enhanced the ability of economists to analyze data. These have allowed economists to construct simulation models which incorporate complex interrelationships among economic variables permitting forecasts better suited to the needs of business and government.

\section{Motivation for the debt simulation model}

Students of undergraduate business and economics who plan to work for government and private organizations, or study for advanced degrees must develop the ability to analyze data using the computer and to make forecasts [1]. Numerous computer models and exercises exist for the introductory and intermediate theory courses which are required for all undergraduate economics majors and many business students [2]. These models increasingly use spreadsheets to help students master economic concepts by manipulating data and graphing relationships [3].

Fewer models have been developed for use by students in more specialized advanced undergraduate courses such as public finance, development economics and labour economics $[4,5]$. This is unfortunate because the students in these advanced courses most need to acquire the skills of the professional economist as described above. It is from these courses that professional economists will be recruited. 
Our model of a developing debtor country was developed for use by advanced undergraduate economics students. Its first goal is to allow students to improve the depth of their understanding of economic concepts specifically the relationship between the international transactions of a country and its international borrowing. The second goal is to take students beyond merely understanding economic relationships into the realm of economic forecasting in the 'real world'. In other words the students can use the model to forecast the ability of a country of their choice to repay its debt in the future. In the process they begin to acquire the skills of data collection, manipulation and interpretation which professional economists use in their work.

\section{Description of the debt simulation model}

Our debt simulation model is similar to others used in government and academic research [6]. It allows users to forecast debt and debt repayments for a fiveyear period. It is based on the balance of payments account which summarizes all the transactions a country makes with other countries. International transactions are of two types: those which earn foreign currencies for a country (sources of foreign exchange such as exports of goods and services, investment by foreigners in the businesses of the given country, loans from foreigners to the given country) and those which require the country in question to transfer foreign currencies to other countries (uses of foreign exchange such as imports of goods and services, investment by the given country overseas, repayment of principal and interest on past loans). The balance of payments accounting identity requires that the sum of all sources of foreign exchange (called credits) equal the sum of all uses of foreign exchange (called debits). Simply said, "the money going out must equal the money coming in".

When the money going out exceeds the money coming in, the country needs to obtain loans from foreign countries (borrowing requirement). The program models how much they need to borrow, the repayment amounts and the cumulative debt levels. We have illustrated this in simplified form in Figure 1 where all of the available sources and uses are given numeric values, and the borrowing requirement is specified as X. It is easily seen that in this case $\mathrm{X}$ must equal 120.

To calculate the desired outputs in the balance of payments model the program requires as input data five values (one for each year the model covers) for each of twenty-five variables. It performs its calculations for each successive year based on the final state at the end of the previous year. This is why an additional set of values representing the initial state of the model is also required as input. 


\begin{tabular}{||lr|lr||}
\hline \multicolumn{2}{|c|}{ Sources of Foreign Exchange (Credits) } & \multicolumn{2}{l|}{ Uses of Foreign Exchange (Debits) } \\
\hline Exports & 100 & Imports & 170 \\
\hline Investment from Foreigners & 50 & Repayment of past loans (i.e. Debt Service) & 100 \\
\hline Loans from Foreigners (i.e Borrowing Requirement) & $\mathrm{X}$ & & 270 \\
\hline \hline & $150+\mathrm{X} \leftarrow$ & must equal $\rightarrow$ & \\
\hline
\end{tabular}

Fig. 1 Computation of borrowing requirement

The program produces five values (one per model year) for each of eight output variables, two of which represent the burden the debt imposes on the borrowing country. These values are the ratios of debt outstanding to export earnings (Debt Export Ratio) and the ratio of debt service to export earnings (Debt Service Ratio). These ratios allow the user of the model to determine whether a given country will have difficulty replaying the debt. A complete list of the variables is provided in Figure 2. The number of output variables is small compared to the number of input variables because the computations of the model are complex and because we purposely limited the number of output values to those which are most critical to an understanding of the debt situation of a developing country.

The user can determine the input values in a variety of ways. The simplest is to gather information on past trends in exports, imports and so on for the relevant country and to assume that those trends continue into the forecast years. The World Bank publishes this type of information for over 100 countries [7].

Although the model is simple to use, the specialized phenomenon with which the model deals (developing country debt), as well as the large volume of data and relationships it involves make the model inappropriate for use in introductory economics courses.

\section{Educational environment}

The model was developed for use in a development economics course at an undergraduate, liberal arts institution. Most of the students in the sevenmember first class were either economics majors or minors at the junior or senior level. All had completed a two semester sequence of principles of microeconomics and macroeconomics. All of the students had some previous experience with a computer. Most were familiar with Word Perfect, some had limited experience with spreadsheets and two had completed one programming class. However there seemed to be very little transfer of prior computer skills to using this computer model. 


\begin{tabular}{|c|c|}
\hline Categories of Inputs & Categaries of Outputs \\
\hline $\begin{array}{l}\text { SinglePeriod Variables } \\
\text { OFFICIAL LONG TERM DEBT -BEGINNING (millions) } \\
\text { PRIVATE LONG TERM DEBT -BEGINNING (millions) } \\
\text { AVERAGE INTEREST RATE -OFFICIAL LONG TERM (\%) } \\
\text { AVERAGE INTEREST RATE -PRIVATE LONG TERM (\%) } \\
\text { ARREARS - BEGINNING (millions) } \\
\text { FOREIGN EXCHANGE RESERVES-BEGINNING (millions) } \\
\text { AMORTIZATION ON OFFICIAL DEBT OUTSTANDING } \\
\text { (millions) } \\
\text { AMORTZATION ON PRIVATE DEBT OUTSTANDING } \\
\text { (millions) } \\
\text { SHORTTERM DEBT-BEGINNING (millions) }\end{array}$ & \multirow[t]{2}{*}{$\begin{array}{l}\text { Multiple Period Variables (one for each forecast } \\
\text { year) } \\
\text { SHORTTERM DEBT(millions) } \\
\text { SCHEDULED INTEREST (millions) } \\
\text { BALANCE ON CURRENT ACCOUNT } \\
\text { (millions) } \\
\text { SCHEDULED DEBTSERVICE (millions) } \\
\text { OFFICIAL LONG TERM DEBT (millions) } \\
\text { PRIVATE LONG TERM DEBT (millions) } \\
\text { DEBTEXPORT RATO (\%) } \\
\text { DEBTSERVICE RATIO (\%) }\end{array}$} \\
\hline $\begin{array}{l}\text { Multiple Period Variables (one for each of } 5 \text { forecast years) } \\
\text { CHANGE IN ARREARS (millions) } \\
\text { GOODSEXPORTED (millions) } \\
\text { GOODSIMPORTED (millions) } \\
\text { SERVICES (excluding interest) EXPORTED (millions) } \\
\text { SERVICES (excluding interest)IMPORTED (millions) } \\
\text { NET TRANSFERS (millions) } \\
\text { CHANGE IN FOREIGN RESERVES (millions) } \\
\text { NET FOREIGN DIRECT INVESTMENT (millions) } \\
\text { ERRORS AND OMISSIONS (millions) } \\
\text { CHANGE IN SHORTTERM DEBT (millions) } \\
\text { PERCENTAGE OF NEW BORROWING -OFFICIAL (\%) } \\
\text { GRACE PERIOD - NEW OFFICIAL LOANS (years) } \\
\text { REPAYMENT PERIOD - NEW OFFICIAL LOANS (years) } \\
\text { AVERAGE INTEREST RATE - NEW OFFICIAL LOANS (\%) } \\
\text { GRACE PERIOD -NEW PRIVATE LOANS (years) } \\
\text { REPAYMENT PERIOD - NEW PRIVATE LOANS (years) } \\
\text { AVERAGE INTEREST RATE - NEW PRIVATE LOANS (\%) } \\
\text { OFFICIAL DEBT RESCHEDULED (millions) } \\
\text { GRACE PERIOD -OFFICAL DEBT RESCHEDULED (years) } \\
\text { REPAYMENT PERIOD - OFFICIAL DEBT RESCHEDULED } \\
\text { (years) } \\
\text { PRIVATE DEBT RESCHEDULED (millions) } \\
\text { GRACE PERIOD -PRIVATE DEBT RESCHEDULED (years) } \\
\text { REPAYMENT PERIOD -PRIVATE DEBT RESCHEDULED } \\
\text { (years) } \\
\text { OFFICIAL DEBT FORGIVEN (millions) } \\
\text { PRIVATE DEBTFORGIVEN (millions) }\end{array}$ & \\
\hline
\end{tabular}

Fig. 2 Program inputs and outputs

The model has also been employed by a student as part of an independent study project on Argentina. In the Spring 1995 semester the model is being used by a class of thirty students studying international finance at a comprehensive state college. 


\section{Brief description of software}

The software was written in Turbo Pascal and runs under DOS. It is available in two versions. The first version of the model prompts the students to enter data interactively. However due to the large number of input values required this is impractical when students need to run the program repeatedly with nearly identical input values. The second version therefore takes its input from a previously prepared data file. In this second version students are given a Word Perfect file which they can edit and save as a DOS textfile. The Word Perfect file contains a variety of markers and labels to facilitate editing it. When the data is saved as a DOS textfile these extraneous and helpful markers disappear leaving a plain ASCII file for the program to read from. The output is written to two distinct files: one echoes the input data received and the other contains the values produced as a result of the program's computations. These files are ASCII textfiles which can easily be viewed on screen using any available editor or printed for viewing away from the computer. In both versions the output file names are hard coded.

\begin{tabular}{||l||}
\hline User (student) errors \\
\hline \hline $\begin{array}{l}\text { 1. datatype errors } \\
\text { keying in non-numeric data such as } \$ \text { or \% } \\
\text { keying in a number with a decimal point when an integer is expected }\end{array}$ \\
\hline $\begin{array}{l}\text { 2. numeric errors } \\
\text { round off errors - occurring as a result of the many computations } \\
\text { underflow/overflow errors - caused when the data values become too large or too small to be } \\
\text { represented with the number of allocated bits } \\
\text { out of range data errors - keying } 3000000 \text { instead of } 3 \text { when the unit is millions }\end{array}$ \\
\hline $\begin{array}{l}\text { 3. unreasonable input errors - caused by entering values that are not wrong in the sense of being impossible } \\
\text { but rather situationally inappropriate. }\end{array}$ \\
\hline \hline Software Development Errors \\
\hline 4. coding errors - caused when the person implementing the code from the algorithms makes a coding error \\
(e.g. subtracts two quantities instead of multiplying them)
\end{tabular}

Fig. 3 Categories of potential computer related errors 


\section{Computer errors and critical thinking}

We feel strongly that students who will be using computers in economic analysis in future, MUST be made aware of the kinds of problems which can and do occur when using computers. Therefore students should be made aware of the potential problems.

Our program guides the students to avoid range and data type errors in their input data. In addition other sources of computer related errors are discussed in class. Figure 3 includes a brief summary of the types of errors covered. The error most heavily emphasized is the one of naive computer users to accept any output produced by the computer as 'gospel'. Students doing pencil and paper computations do not have the blind faith in their results which they often display in the output from a computer. Students need to be taught to examine the program's output critically and to question what can not be reconciled with the input data.

We elected not to have the program alert students when the output values were unreasonable, because we wanted students to learn to recognize such output and to trace through the model's relationships to identify the sources. This enhances logical reasoning, a critical skill for economists. One of the exercises shown in Figure 4 is aimed at producing such output.

\section{Initial classroom use of the model}

As discussed earlier the goals were to enhance student understanding of concepts and relationships underlying the accumulation and repayment of foreign debt by developing countries, and to give students a start in acquiring the skills of data collection, manipulation and interpretation they will require when working as professional economists. The students in the first class to use the model made great strides in achieving these goals.

On the first goal the students demonstrated improved understanding of the factors influencing debt accumulation and repayment compared with previous classes. On exams and papers students showed a clearer comprehension of the consequences of the various schemes bankers and government officials implemented in the 1980's to restore the ability of debt burdened developing countries to repay loans.

The second goal was fostered by having the students manipulate the model individually and analyze the results. The first class using the model employed it as part of a research paper. Each of the students chose a country, developed a set of input data, ran the program on the data and included an analysis of the output data produced in the paper. 
They learned some of the elements required to write an economics research report including describing economic relationships in ways which can be understood by persons without training in economics and which justify the assumptions under which input data are developed. One student from this class told us that the deciding factor in her getting an internship was her experience using the model. There were additional positive outcomes. Students were more interested in the topic than they had been in previous semesters. Class sessions in which the model and its implications were discussed, were livelier than the average discussion class with more students participating.

Students spent considerable time outside class on the project involving the model. The number of questions they asked outside class seemed endless. The model fostered a more cooperative effort among the students as they voluntarily worked with each other to learn the model and solve computer related problems.

We believe that these positive outcomes were the result of two factors at play.

\begin{tabular}{|c|c|}
\hline \multicolumn{2}{|r|}{ Graduated Series of Ex ercises } \\
\hline & Ex ercise 1: \\
\hline Activity & Students attend a lecture on the purpose and use of the model \\
\hline \multirow[t]{2}{*}{ Goal } & To enable students to understand the model's underlying logic and appropriate uses of the model. \\
\hline & Exercise 2: \\
\hline Activity & Students run the program with data already loaded into the datafile. \\
\hline Goal & $\begin{array}{l}\text { To ensure that al students are capable of ruming a program on the computer and obtaining a } \\
\text { printout of the output. }\end{array}$ \\
\hline \multirow[t]{2}{*}{ Follow up } & Discuss the significance of the output (relate the output to the input). \\
\hline & Exercise 3: \\
\hline Activity & $\begin{array}{l}\text { Students modify the existing datafile several times as specified by the instructor and run the } \\
\text { program with each modification of the datafile. One or more of the modifications may be designed } \\
\text { to illustrate data range value erros. }\end{array}$ \\
\hline Goal & To enable students to modify the program's input data. \\
\hline Follow up & $\begin{array}{l}\text { Discuss the difference in the output as it relates to the altered input and any problems that arose in } \\
\text { altering the data and running the program. }\end{array}$ \\
\hline
\end{tabular}




\begin{tabular}{||l|l||}
\hline & \multicolumn{1}{c|}{ Ex ercise 4: } \\
\hline \hline Activity & Students modify an existing datafile (or create an entirely new one) with values of their choice \\
\hline Goal & To have students progress toward independent generation and analysis of data \\
\hline Follow up & $\begin{array}{l}\text { Have students form groups and analyze each other's input and output (group process provides a non- } \\
\text { threatening environment for articulating observations relating to the data). }\end{array}$ \\
\hline \hline Activity & $\begin{array}{l}\text { Each student is asked to develop a complete set of input data for a third world country of his or her } \\
\text { choice and to analyze the output generated by the computer model. }\end{array}$ \\
\hline Goal & $\begin{array}{l}\text { To enable students to make their own forecast and demonstrate their knowledge of the repercussions } \\
\text { of international borrowing interest rates and repayment schedules in terms of a developing country's } \\
\text { ability to meet their debt obligations. }\end{array}$ \\
\hline Follow up & $\begin{array}{l}\text { Write a report to accompany the computer output which explains the output data as it relates to the } \\
\text { input data. }\end{array}$ \\
\hline \hline
\end{tabular}

Fig. 4 Sample Exercises

Firstly the computer allowed the students to take an active part in their learning as opposed to the more passive role they play in lecture style learning. Secondly students were excited to use a model which allows analysis of the prospects for a real-world country. Many economics courses teach primarily abstract theory. Students found it refreshing to see how economic ideas can be used to illuminate real-world issues and situations.

\section{Hints for using the model in the classroom}

We encountered three unanticipated difficulties.

The first relates to student understanding of the logic of the model. The debt simulation model links the inputs algebraically to the outputs. Thorough understanding requires the ability to trace through a chain of algebraic equations which build upon one another. We anticipated that some students would be deficient in this skill. The solution tried was to present a scaled-down version of the model's logic before the students attempted their first manipulation of the model. In addition students received a manual which included all the equations used in the model. Despite understanding the logic of the scaled-down version many students had difficulty replicating the computations by hand in the more complex version they subsequently used. Apparently mastery of a simplified version was not sufficient for complete understanding of the more complex version.

Secondly students also must have sufficient understanding of the range of permissible and realistic values for both inputs and outputs to use the model effectively. As the program does not alert students to unreasonable output 
values, they must receive some instruction in identifying unreasonable values. The economics instructor gave some classroom instruction in this area, but never showed students examples of unreasonable output values generated by the computer model. Consequently students panicked when they inadvertently generated inappropriate output values. The students required more systematic information on identifying the sources of unreasonable output values than the economics instructor provided.

The final difficulty concerns the appropriate time to introduce the model to the students. This depends on the type and difficulty of the assignments the students will do with the model. Figure 4 shows a series of exercises which allow students to progress gradually from being novice users of the model (Exercise 1) to experts who can make forecasts for countries of their own choosing (Exercise 5). The students in the first class to use the model were expected to make their own forecasts. These students did however not see the model until two-thirds of the way through the semester and consequently several of them did not have enough time to thoroughly master the model's relationships before starting to gather the data required to do their own forecasts. The model should therefore be introduced in the first half of the semester. The students in the second class were only expected to use the model with input data they produce by modifying existing data sets (Exercises 1-4). In this environment, we believe the model can be introduced as late as the last third of the semester.

\section{SUMMARY}

We have reported on the successful creation and use of a computer debtsimulation model in an advanced undergraduate economics course. We have included descriptions of the model and the pedagogical issues we feel are relevant. We plan to use the model in future courses and to involve computer science students in designing additional modules to expand the model. The time and effort we spent was well compensated for by the improved learning environment the model provided.

\section{REFERENCES}

1. Siegfried, J. J. et al. (1991) The Status and Prospects of the Economics Major. Journal of Economic Education, 22 (3) pp. 197-224. 
Creating and using a computer debt simulation model for teaching the economics of 1009 developing countries

2. Walbert, M. S. (1989) Writing Better Software for Economics Principles Textbooks. Journal of Economic Education, 20 (3) pp. 281-89.

3. Ciolfi, Q. P. (1990) Using Computers to Teach Microeconomics: Principles of Profit Maximization. Florida Educational Computing Quarterly, 3 (1) pp. 32-39.

4. Seiver, D. A. (1983) Fredonia: A Simulation Model for Teaching Undergraduate Development Economics. Journal of Development Economics, 13 (1) pp. 103-07.

5. Coffin, D. A. (1993) Using the Competitive Edge. Journal of Economic Education, 24 (1) pp. 62-69.

6. McSwain, R. (1986) The EB/PAS Balance of Payments Model. U.S. Department of State, mimeo.

7. World Bank (1993) World Debt Tables, 1993-94. 